Original article

\title{
Morphometric analysis of Apis cerana populations in the southern Himalayan region
}

\author{
H. Randall HePBURN ${ }^{\mathrm{a} *}$, Sarah E. RADLOFF ${ }^{\mathrm{b}}$, S. VERMA ${ }^{\mathrm{c}}$, \\ L.R. VERMA ${ }^{\mathrm{c}}$ \\ ${ }^{a}$ Department of Zoology and Entomology, Rhodes University, Grahamstown, 6140 South Africa \\ ${ }^{b}$ Department of Statistics, Rhodes University, Grahamstown, 6140 South Africa \\ ${ }^{c}$ Department of Bio-Sciences, Himachal Pradesh University, Shimla 171005, HP, India
}

(Received 6 February 2001; revised 23 May 2001; accepted 29 June 2001)

\begin{abstract}
Multivariate analyses of morphometric traits of Apis cerana were measured from 3704 individual workers of 279 colonies from 64 localities with an average sampling distance resolution of $50 \mathrm{~km}$ along a $2200 \mathrm{~km}$ transect in the southern Himalayan region bordered by Pakistan to the west and Myanmar to the east. Factor and discriminant function analyses revealed four major morphoclusters (= unnamed subspecies), two of which are further subdivisable into three biometric subgroups each. These morphoclusters can only be partially integrated into any current subspecific nomenclature available for Apis cerana. Morphocluster separation is related to physiographic differences which create a partial temporal reproductive isolation associated with altitude. High variance domains occur at the edges of morphocluster and biometric groupings. The bees decrease in size from west to east but increase in size with increasing altitude.
\end{abstract}

Apis cerana / honeybees / morphoclusters / population genetics / southern Himalayas

\section{INTRODUCTION}

In many ways $A$. cerana Fabr. is the oriental equivalent of its occidental counterpart A. mellifera L., both having equally wide areas of distribution and spectra of adaptations (Ruttner, 1988). However, multivariate morphometric analyses of the former lag behind the latter and a recent survey of the literature shows that infraspecific classification and population structure in Apis cerana are fraught with difficulties (Hepburn et al., 2001). A beginning toward a resolution of this disparity is apparent from the recent publication of several such analyses for different parts of Asia (Sasaki, 1994;

* Correspondence and reprints

E-mail: r.hepburn@ ru.ac.za 
Deowanish et al., 1996; Damus and Otis, 1997; Sylvester et al., 1998; Sihanuntavong et al., 1999; de la Rúa et al., 2000; Smith et al., 2000; Tilde et al., 2000).

The southern Himalayan region and surrounds are particularly interesting in this context because analyses of morphological variation extend well into the past (e.g. Kapil, 1956; Narayanan, 1960,1961a,b; Kshirsagar, 1973). While the earlier studies were univariate in approach, some more recent works have been fully multivariate in the analysis of Himalayan honeybees (Verma et al., 1989, 1994; Singh et al., 1990; Singh and Verma, 1993). Although this suite of four papers treated the western, central and eastern subregions, some rather large gaps precluded a unified multivariate analysis of the whole, contiguous region. The recent acquisition of substantially more data from former lacunae now permits a complete multivariate morphometric analysis of population structure in A. cerana in the southern Himalayan region, extending from the northeastern border of Pakistan to the northwestern border of Myanmar at an average interlocality resolution of $50 \mathrm{~km}$. This allows for extensive analyses of the honeybee size-altitude relationship, delineation of clines, correlations between morphocluster distribution and physiography, and the nature of morphometric high variance domains.

\section{MATERIALS AND METHODS}

\subsection{Honeybees}

The workers of A. cerana used in this analysis include all the original unpublished raw data for 44 localities used in previous studies of the southern Himalayan region (Verma et al., 1989, 1994; Singh et al., 1990; Singh and Verma, 1993) (Tab. I). In these studies sample sizes were 60 bees/colony and 4-5 colonies/locality for the western and central subregions and 10 to 20 bees/ colony and 3-6 colonies/locality in the eastern sector. In addition honeybees from 20 new localities were collected and 20 bees/ colony and 3-4 colonies/locality were measured (Tab. I). All these localities are also mapped (Figs. 1 and 2).

Table I. Localities from which A. cerana were collected along a $2200 \mathrm{~km}$ transect in the southern Himalayan region (* new localities).

\begin{tabular}{|c|c|c|c|c|c|}
\hline \multirow{2}{*}{$\frac{\text { No. }}{1 .}$} & \multirow{2}{*}{$\begin{array}{l}\text { Localities } \\
\text { Kupwara }\end{array}$} & \multicolumn{2}{|c|}{ Coordinates } & \multirow{2}{*}{$\begin{array}{c}\text { Altitude } \\
1811\end{array}$} & \multirow{2}{*}{$\begin{array}{c}\text { Swarming time } \\
\text { April }\end{array}$} \\
\hline & & $34.31 \mathrm{~N}$ & $74.16 \mathrm{E}$ & & \\
\hline 2. & Gurais & $34.37 \mathrm{~N}$ & $74.53 \mathrm{E}$ & 2364 & April \\
\hline 3. & Tral & $33.56 \mathrm{~N}$ & $75.10 \mathrm{E}$ & 2007 & April \\
\hline 4. & Dras & $34.26 \mathrm{~N}$ & $75.46 \mathrm{E}$ & 2977 & April \\
\hline 5. & Srinagar & $34.08 \mathrm{~N}$ & $74.50 \mathrm{E}$ & 1768 & April \\
\hline 6. & Sonamarg & $34.18 \mathrm{~N}$ & $75.21 \mathrm{E}$ & 2740 & April \\
\hline 7. & Rajouri & $33.23 \mathrm{~N}$ & $74.21 \mathrm{E}$ & 938 & February \\
\hline 8. & Kishtwar & $33.19 \mathrm{~N}$ & $75.48 \mathrm{E}$ & 1664 & April \\
\hline 9. & Dalhousie & $32.32 \mathrm{~N}$ & $75.58 \mathrm{E}$ & 2036 & April \\
\hline 10. & Kangra & $32.05 \mathrm{~N}$ & $76.16 \mathrm{E}$ & 700 & February \\
\hline 11. & Katrain & $32.05 \mathrm{~N}$ & $77.08 \mathrm{E}$ & 1463 & March \\
\hline 12. & Pooh & $31.40 \mathrm{~N}$ & $78.34 \mathrm{E}$ & 2837 & April \\
\hline 13. & Bhareri & $31.23 \mathrm{~N}$ & $76.34 \mathrm{E}$ & 1007 & March \\
\hline 14. & Mandi & $31.43 \mathrm{~N}$ & $76.50 \mathrm{E}$ & 761 & February \\
\hline 15. & Roghi & $31.32 \mathrm{~N}$ & $78.15 \mathrm{E}$ & 3017 & April \\
\hline 16. & Bilaspur & $31.15 \mathrm{~N}$ & $76.40 \mathrm{E}$ & 587 & February \\
\hline
\end{tabular}


Table I. (Continued).

\begin{tabular}{|c|c|c|c|c|c|}
\hline \multirow{2}{*}{$\begin{array}{l}\text { No. } \\
17 .\end{array}$} & \multirow{2}{*}{$\begin{array}{c}\text { Localities } \\
\text { Bagi }\end{array}$} & \multicolumn{2}{|c|}{ Coordinates } & \multirow{2}{*}{$\begin{array}{c}\text { Altitude } \\
2648\end{array}$} & \multirow{2}{*}{$\begin{array}{c}\text { Swarming time } \\
\text { April }\end{array}$} \\
\hline & & $31.15 \mathrm{~N}$ & $77.27 \mathrm{E}$ & & \\
\hline 18. & Shimla & $31.07 \mathrm{~N}$ & $77.10 \mathrm{E}$ & 2206 & April \\
\hline 19. & Solan & $30.50 \mathrm{~N}$ & $77.08 \mathrm{E}$ & 1530 & April \\
\hline 20. & Nahan & $30.33 \mathrm{~N}$ & $77.21 \mathrm{E}$ & 905 & February \\
\hline 21. & Dehradun* & $30.30 \mathrm{~N}$ & $78.08 \mathrm{E}$ & 762 & February \\
\hline 22. & Haridwar* & $30.02 \mathrm{~N}$ & $78.04 \mathrm{E}$ & 330 & February \\
\hline 23. & Pauri* & $30.12 \mathrm{~N}$ & $78.48 \mathrm{E}$ & 1550 & April \\
\hline 24. & Chaubattia* & $29.55 \mathrm{~N}$ & $79.00 \mathrm{E}$ & 2122 & April \\
\hline 25. & Almora* & $29.36 \mathrm{~N}$ & $79.40 \mathrm{E}$ & $\approx 1750$ & April \\
\hline 26. & Nainital* & $29.23 \mathrm{~N}$ & $79.32 \mathrm{E}$ & 1920 & April \\
\hline 27. & Jeolikote* & $29.16 \mathrm{~N}$ & $79.46 \mathrm{E}$ & 1250 & March \\
\hline 28. & Haldwani* & $29.13 \mathrm{~N}$ & $79.31 \mathrm{E}$ & $\approx 800$ & February \\
\hline 29. & Budaun* & $28.02 \mathrm{~N}$ & 79.07E & $\approx 150$ & February \\
\hline 30. & Lucknow* & $26.50 \mathrm{~N}$ & $80.54 \mathrm{E}$ & $\approx 150$ & February \\
\hline 31. & Lohaghat* & $29.25 \mathrm{~N}$ & $80.06 \mathrm{E}$ & $\approx 1200$ & March \\
\hline 32. & Lali* & $29.49 \mathrm{~N}$ & $80.36 \mathrm{E}$ & 1097 & March \\
\hline 33. & Sharmali* & $29.14 \mathrm{~N}$ & $80.25 \mathrm{E}$ & 1635 & April \\
\hline 34. & Navadurga* & $29.15 \mathrm{~N}$ & $80.27 \mathrm{E}$ & 1837 & April \\
\hline 35. & Lanakedareshwar* & $29.22 \mathrm{~N}$ & $80.56 \mathrm{E}$ & 1360 & March \\
\hline 36. & Durg* & $29.10 \mathrm{~N}$ & $81.20 \mathrm{E}$ & 1345 & March \\
\hline 37. & Ghughuti* & $29.18 \mathrm{~N}$ & $82.12 \mathrm{E}$ & 2470 & April \\
\hline 38. & Vinaula* & $29.18 \mathrm{~N}$ & $82.18 \mathrm{E}$ & 2895 & April \\
\hline 39. & Liwang & $28.25 \mathrm{~N}$ & $82.40 \mathrm{E}$ & 1500 & April \\
\hline 40. & Laltibang & $28.20 \mathrm{~N}$ & $82.30 \mathrm{E}$ & 900 & February \\
\hline 41. & Ghorahi & $28.05 \mathrm{~N}$ & $82.20 \mathrm{E}$ & 400 & February \\
\hline 42. & Lumle & $28.20 \mathrm{~N}$ & $84.00 \mathrm{E}$ & 1400 & March \\
\hline 43. & Tansen & $27.55 \mathrm{~N}$ & $83.40 \mathrm{E}$ & 1067 & March \\
\hline 44. & Sidheshwar* & $27.18 \mathrm{~N}$ & $85.56 \mathrm{E}$ & 1463 & March \\
\hline 45. & Suspa* & $27.44 \mathrm{~N}$ & $86.10 \mathrm{E}$ & 1600 & April \\
\hline 46. & Letang & $26.40 \mathrm{~N}$ & $87.25 \mathrm{E}$ & 250 & February \\
\hline 47. & Homtang & $27.10 \mathrm{~N}$ & $87.10 \mathrm{E}$ & 600 & February \\
\hline 48. & Virgaon & $27.05 \mathrm{~N}$ & $87.51 \mathrm{E}$ & 1200 & March \\
\hline 49. & Kurseong & $26.56 \mathrm{~N}$ & $88.20 \mathrm{E}$ & 1458 & March \\
\hline 50. & Gangtok & $27.02 \mathrm{~N}$ & $88.40 \mathrm{E}$ & 1818 & April \\
\hline 51. & Bongaigaon & $26.28 \mathrm{~N}$ & $90.32 \mathrm{E}$ & 76 & February \\
\hline 52. & Khoirabari & $26.38 \mathrm{~N}$ & $91.51 \mathrm{E}$ & 134 & February \\
\hline 53. & Guwahati & $26.11 \mathrm{~N}$ & $91.47 \mathrm{E}$ & 56 & February \\
\hline 54. & Shillong & $25.34 \mathrm{~N}$ & $91.56 \mathrm{E}$ & 1496 & March \\
\hline 55. & Silchar & $24.50 \mathrm{~N}$ & $92.51 \mathrm{E}$ & 67 & February \\
\hline 56. & Aizawl & $23.45 \mathrm{~N}$ & $92.45 \mathrm{E}$ & 1132 & March \\
\hline 57. & Itanagar & $27.08 \mathrm{~N}$ & $93.40 \mathrm{E}$ & 550 & February \\
\hline 58. & Dimapur & $25.54 \mathrm{~N}$ & $93.48 \mathrm{E}$ & 160 & February \\
\hline 59. & Мао & $25.30 \mathrm{~N}$ & $94.07 \mathrm{E}$ & 2012 & April \\
\hline 60. & Kohima & $25.41 \mathrm{~N}$ & $94.06 \mathrm{E}$ & 1495 & March \\
\hline 61. & Ukhrul & $25.08 \mathrm{~N}$ & $94.23 \mathrm{E}$ & 1829 & April \\
\hline 62. & Imphal & $24.49 \mathrm{~N}$ & $93.58 \mathrm{E}$ & 792 & February \\
\hline 63. & Moirang & $24.30 \mathrm{~N}$ & $93.48 \mathrm{E}$ & 782 & February \\
\hline 64. & Churachandpur & $24.20 \mathrm{~N}$ & $93.40 \mathrm{E}$ & 914 & February \\
\hline
\end{tabular}




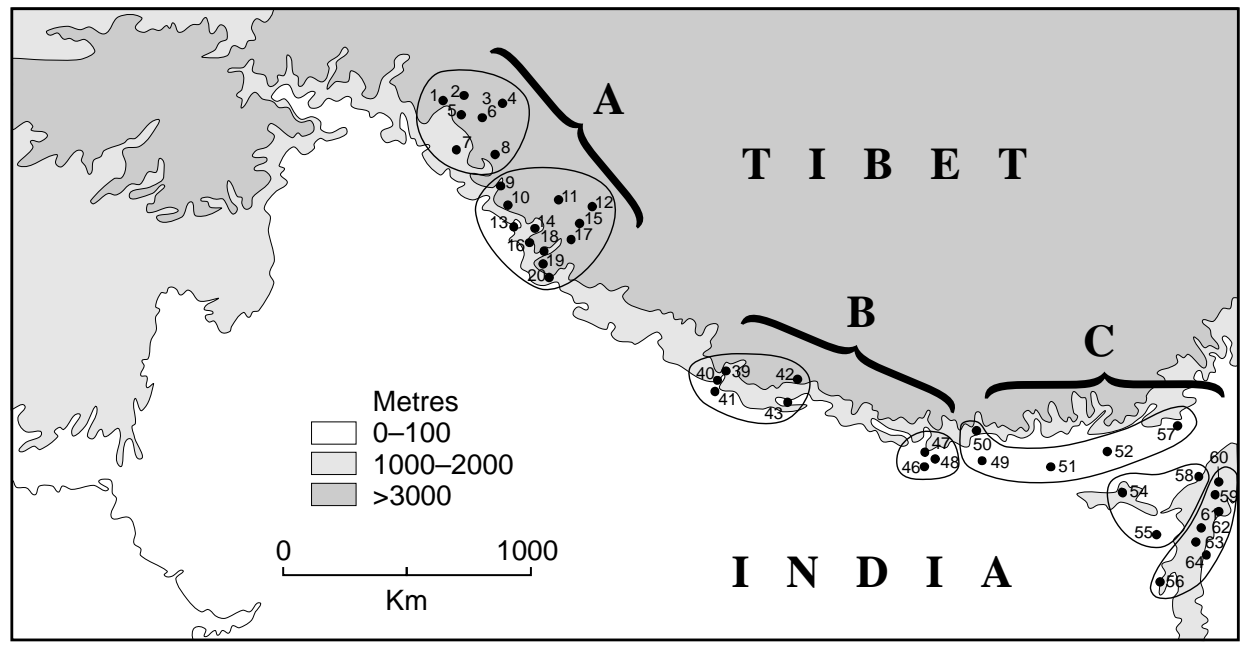

Figure 1. Composite distribution of the biometric groups of A. cerana previously identified in the southwestern (Verma et al., 1989, 1994) and southeastern (Singh et al., 1990; Singh and Verma, 1993) Himalayan subregions. Locality numbers are the same as in Figure 2 and details given in Table I. The biometric groups from west to east are: A-(1) Kashmir, (2) Himachal Pradesh, B-(3) Nepali Terai plains, (4) Nepali Midland Hills, C-(5) Himalaya (Sikkim, west Bengal, Assam and Arunachal Pradesh), (6) Brahmaputra (Assam and Meghalaya) and (7) Nagaland (Nagaland, Manipur and Mizoram).

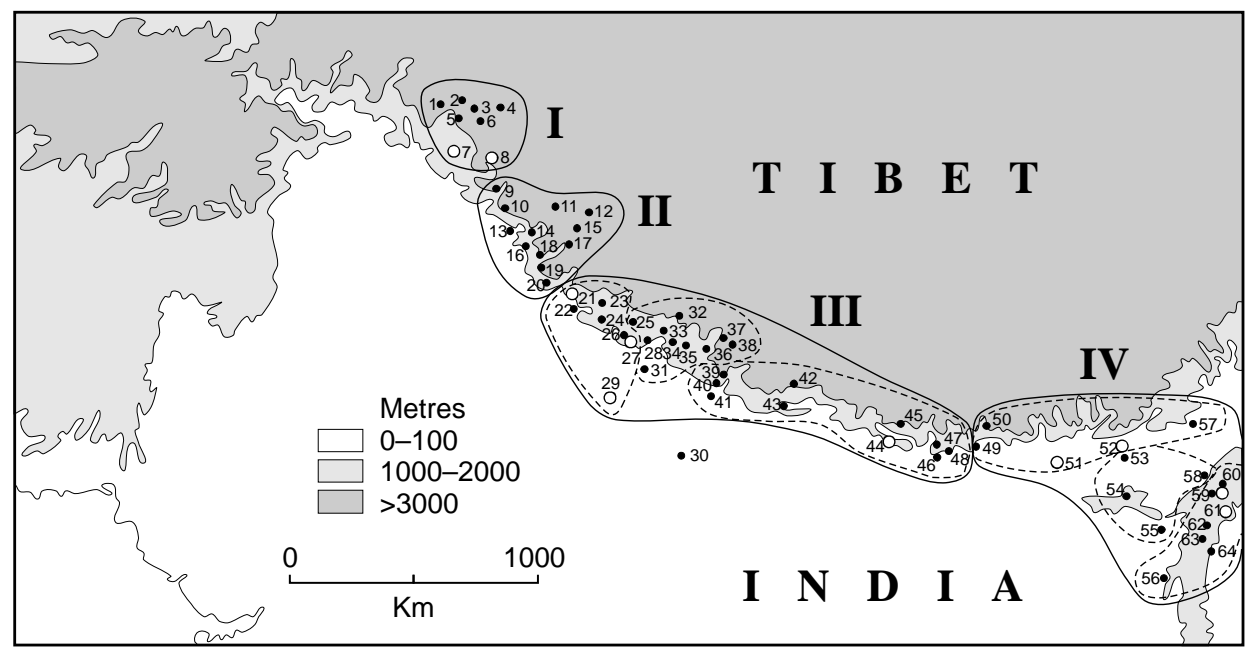

Figure 2. Morphoclusters of A. cerana obtained by multivariate analysis of bees of the southern Himalayan region along a $2200 \mathrm{~km}$ transect with a $50 \mathrm{~km}$ interlocality sampling resolution between 64 localities. The morphoclusters occur as follows: I Kashmir; II Himachal Pradesh; III Uttar Pradesh and Nepal; IV Sikkim, Bengal and NE states of India. Morphoclusters III and IV are further resolved into three biometric subgroups each from west to east as follows: IIIa Uttar Pradesh, IIIb W. Nepal, IIIc central and E. Nepal; IVa Sikkim, Bengal, Assam and Arunachal Pradesh, IVb Assam and Meghalaya, IVc Nagaland, Manipur and Mizoram. Names of localities are given in Table I. Open circles denote localities of significantly high morphometric variance. 


\subsection{Measurements and analysis}

Fifty-five quantitative morphological characters previously used (Verma et al., 1989, 1994; Singh et al., 1990; Singh and Verma, 1993) were measured for the new localities in this study. The first statistical procedure was to perform a factor analysis on the colony means using these 55 characters for all 3704 bees collected across the entire transect. This procedure established which characters have larger loadings in the various factors and allows the parsimonious reduction in the number of characters actually needed for further analysis. The next procedure was a correlation analysis of the colony means for all 55 characters to determine which characters were highly correlated. If two or more characters with high factor loadings (greater than 0.6) were highly correlated $(r>0.8)$, then only one was selected for further analyses. Finally, a factor analysis for the whole transect using colony means for the remaining 22 selected characters was performed, followed by a discriminant analysis of colony means for these 22 characters to determine colony groupings (morphoclusters). A jackknife procedure was used to classify each colony into a morphocluster with the highest posterior probability according to the discrimination function (Lachenbruch and Mickey, 1968). Wilks' Lambda statistic was used to test for significant differences between the vector of means of the characters entered into the discriminant functions. The intercolonial variances at each locality were tested for heterogeneity by means of Levene's F Statistic (Johnson and Wichern, 1998).

\section{RESULTS}

The factor and correlation analyses procedures using the colony means of the 55 morphometric characters of worker honeybees from the 64 localities resulted in the following 22 morphometric characters for further analysis: (numbers in brackets refer to schemes of Verma et al., 1989, 1994; Singh et al., 1990; Singh and Verma, 1993): forewing-length of radial cell (1), length of apical position of radial cell (4), length of forewing (5); angles of venation- (10), (11), (13); hindwing-length of basal portion of radial vein (20), number of hamuli (26), length of vannal lobe (29); hindleg-length of femur (30), length of tibia (31), length of metatarsis (32); tongue-total length of tongue (36), length of labial palp (37); abdomen-total length of 3rd tergite (42), length of dark band of 4th tergite (44), total length of 4th tergite (45), length of wax mirror on 3rd sternite (48), total length of 3rd sternite (49), length or depth of 6th sternite (50); antenna-length of flagellum (54), total length of antenna (55).

A factor analysis using the colony means of the selected 22 characters of worker honeybees from the entire transect isolated three factors with eigenvalues greater than one. Factor 1: characters associated with the size of the honeybees; Factor 2: angle of venation (10); and Factor 3: angles of venation (11) and (13). These three factors accounted for $78.6 \%$ of the variance in the data. The loadings for each character had an absolute value greater than 0.6. A graph of the factor scores revealed four morphoclusters, those colonies from the Kashmir region forming one cluster (I), those colonies from the Himachal region forming a second cluster (II), those from Uttar Pradesh and Nepal regions forming a third cluster (III), and those from the northeast Himalayan region forming a fourth cluster (IV) (Figs. 2 and 3). The colonies from two localities at high altitudes, Ghughuti (2470 m) and Vinaula (2895 m), formed their own cluster (Fig. 3). The 5 colonies from Lucknow (30) appeared in the far left-hand of the third morphocluster indicating that the bees from this region are smaller and probably belong to a southern Indian morphocluster not defined here (Fig. 3). The graph of the factor scores confirms the results of Verma et al. (1989, 1994) that Nepali bees are smaller in size than 


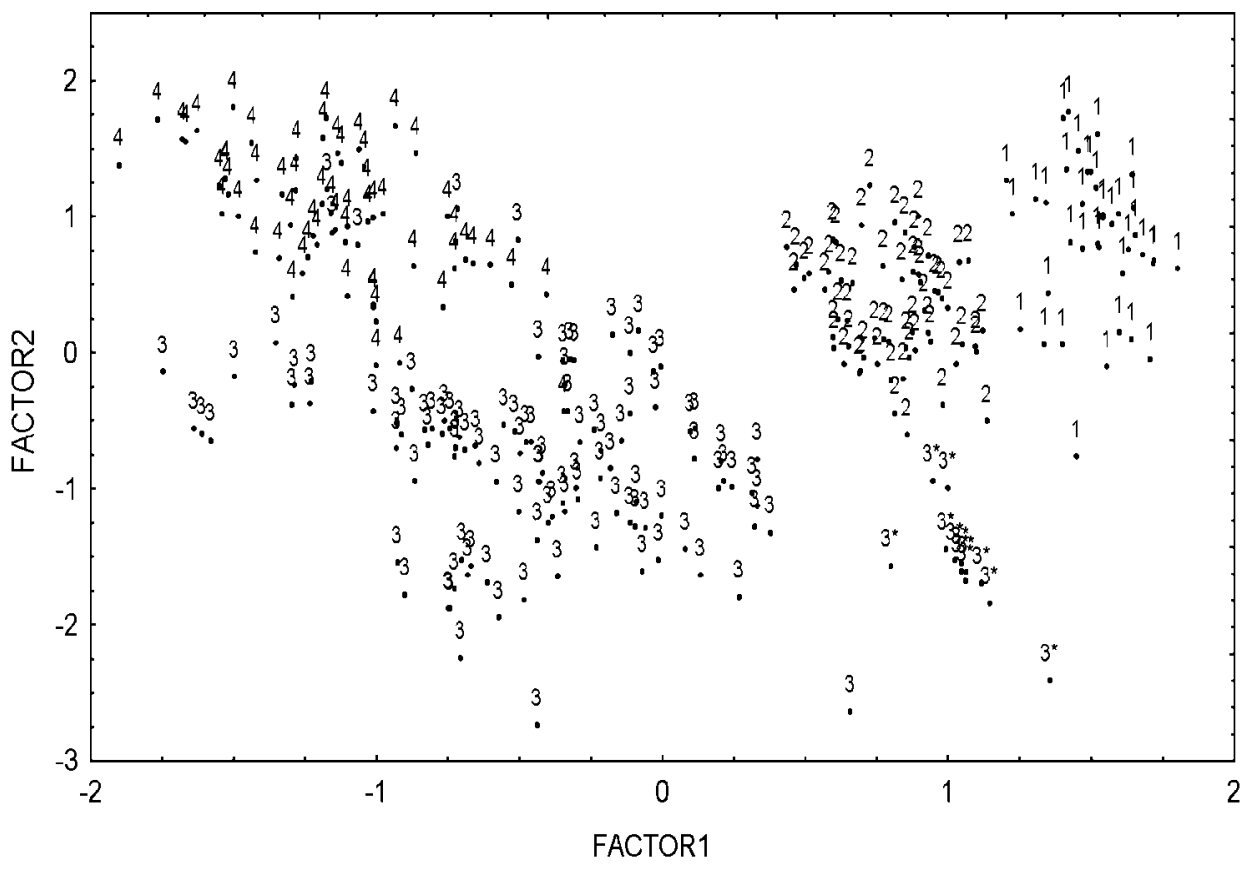

Figure 3. Factor analysis plot of the southern Himalayan morphoclusters of A. cerana using 22 morphometric characters: morphocluster I comprises colonies from Kashmir; morphocluster II comprises colonies from Himachal Pradesh; III of colonies from Uttar Pradesh and Nepal and IV colonies from the northeast Himalayan region. Morphoclusters in figure are represented in Arabic numbers to avoid confusion of overlapping amongst Roman numbers. The colonies from Ghughuti and Vinaula are denoted by $3^{*}$.

Kashmiri and Himachali bees, but bigger than Manipuri bees.

A discriminant analysis confirmed the four morphoclusters with $100 \%$ correct classification of the 39 colonies from the Kashmir region with a posteriori probabilities equal to one for all colonies. Likewise, there was a $100 \%$ correct classification of the 60 colonies from the Himachal region with a posteriori probabilities equal to one for all colonies. Also, there was a $97.5 \%$ correct classification of the 121 colonies from Uttar Pradesh and Nepal regions (3 misclassified from Almora into morphocluster IV) with a posteriori probabilities equal to 1 for 111 colonies, $0.990<P<0.996$ for 3 colonies, $0.95<P<0.98$ for 2 colonies, $P=0.82$ for 1 colony and $P=0.51$ for
1 colony. Finally there was a $98.3 \%$ correct classification of the 59 colonies from the northeast Himalayan region (1 misclassified from Bongaigaon into morphocluster III) with a posteriori probabilities equal to one for all colonies. The overall classification rate was $98.6 \%$. The jackknife procedure gave the same classification results, except one more colony from Almora was classified incorrectly into morphocluster IV; i.e., $97.8 \%$ correct classification rate. A significant difference was found among the means of the four clusters $[\Lambda=0.0002$ with $(17,3$, 275) df; $F=249.7$ with $(51,771) \mathrm{df}$, $P<0.0001]$. Seventeen of the 22 morphometric characters which entered into the discriminant function in descending order of discriminating power are as follows: (48), (37), (1), (36), (10), (29), (45), (11), (13), 
(5), (55), (54), (31), (30), (44), (50), and (42). The means and standard deviations of the 22 characters for each morphocluster are given in Table II.

A factor analysis carried out using the 59 colonies from the northeast Himalayan region alone (morphocluster IV) at a mean sampling distance resolution of approximately $50 \mathrm{~km}$ showed morphological differences amongst the localities. Three biometric groups were found, group (a) comprising colonies from the foothills of

Table II. Means and standard deviations (sd) of 22 morphometric characters (measurements in mm, angles in degrees) for four morphoclusters of southern Himalayan A. cerana.

\begin{tabular}{|c|c|c|c|c|c|c|c|c|}
\hline \multirow[b]{3}{*}{ Character } & \multicolumn{8}{|c|}{ Morphoclusters } \\
\hline & \multicolumn{2}{|c|}{$\begin{array}{c}\mathrm{I} \\
n=39\end{array}$} & \multicolumn{2}{|c|}{$\begin{array}{c}\text { II } \\
n=60\end{array}$} & \multicolumn{2}{|c|}{$\begin{array}{c}\text { III } \\
n=121\end{array}$} & \multicolumn{2}{|c|}{$\begin{array}{c}\text { IV } \\
n=59\end{array}$} \\
\hline & Mean & sd & Mean & sd & Mean & sd & Mean & sd \\
\hline \multicolumn{9}{|l|}{ Forewing } \\
\hline (1) & 3.18 & 0.03 & 3.01 & 0.03 & 2.97 & 0.09 & 2.89 & 0.06 \\
\hline (4) & 1.95 & 0.04 & 1.85 & 0.03 & 1.81 & 0.05 & 1.76 & 0.04 \\
\hline (5) & 8.75 & 0.05 & 8.50 & 0.08 & 8.28 & 0.29 & 8.21 & 0.15 \\
\hline \multicolumn{9}{|l|}{ Angle } \\
\hline (10) & 107.67 & 1.59 & 107.50 & 1.42 & 104.80 & 2.33 & 109.57 & 2.33 \\
\hline (11) & 95.66 & 1.66 & 93.78 & 1.17 & 93.11 & 2.17 & 93.85 & 1.66 \\
\hline (13) & 90.55 & 1.11 & 88.37 & 0.83 & 91.09 & 4.93 & 88.15 & 1.73 \\
\hline \multicolumn{9}{|l|}{ Hindwing } \\
\hline (20) & 1.48 & 0.02 & 1.44 & 0.02 & 1.36 & 0.05 & 1.33 & 0.03 \\
\hline (26) & 19.44 & 1.02 & 19.36 & 0.91 & 17.72 & 0.66 & 18.20 & 0.79 \\
\hline (29) & 1.24 & 0.03 & 1.20 & 0.03 & 1.12 & 0.03 & 1.14 & 0.02 \\
\hline \multicolumn{9}{|l|}{ Hindleg } \\
\hline (30) & 2.58 & 0.03 & 2.47 & 0.03 & 2.34 & 0.12 & 2.30 & 0.03 \\
\hline (31) & 3.20 & 0.03 & 3.09 & 0.03 & 2.90 & 0.03 & 2.88 & 0.02 \\
\hline (32) & 2.01 & 0.03 & 1.94 & 0.03 & 1.81 & 0.08 & 1.79 & 0.03 \\
\hline \multicolumn{9}{|l|}{ Tongue } \\
\hline (36) & 5.35 & 0.14 & 5.31 & 0.13 & 4.46 & 0.48 & 4.65 & 0.08 \\
\hline (37) & 2.75 & 0.07 & 2.55 & 0.04 & 2.12 & 0.12 & 2.13 & 0.04 \\
\hline \multicolumn{9}{|l|}{ Abdomen } \\
\hline (42) & 2.10 & 0.02 & 1.98 & 0.03 & 1.75 & 0.20 & 1.70 & 0.04 \\
\hline$(44)$ & 1.20 & 0.03 & 1.09 & 0.03 & 0.95 & 0.10 & 0.88 & 0.10 \\
\hline (45) & 2.06 & 0.03 & 1.90 & 0.02 & 1.73 & 0.07 & 1.67 & 0.05 \\
\hline (48) & 1.24 & 0.02 & 1.52 & 0.01 & 1.10 & 0.06 & 0.93 & 0.04 \\
\hline (49) & 2.60 & 0.02 & 2.43 & 0.03 & 2.29 & 0.08 & 2.25 & 0.06 \\
\hline$(50)$ & 2.40 & 0.02 & 2.32 & 0.04 & 2.16 & 0.07 & 2.13 & 0.05 \\
\hline \multicolumn{9}{|l|}{ Antenna } \\
\hline (54) & 2.72 & 0.02 & 2.54 & 0.02 & 2.31 & 0.16 & 2.49 & 0.03 \\
\hline (55) & 4.31 & 0.02 & 4.11 & 0.03 & 3.70 & 0.15 & 3.78 & 0.04 \\
\hline
\end{tabular}


the Himalayas, group (b) comprising colonies from the Brahmaputra valley and Khasi Hills, and group (c) colonies from the Naga and Mizo Hills (Fig. 2). The factor analysis isolated six factors with eigenvalues greater than one. The first three factors associated with size of the bees; factors 4 and 5 associated with angles of wing venation; and factor 6 having the number of hamuli (26) as the larger factor loading character.

The factor scores plot showed that the bees from the Naga and Mizo Hills are smaller than those of the Brahmaputra Valley, the Khasi Hills and from the foothills of the Himalayas. A discriminant analysis confirmed the three biometric groups with $100 \%$ correct classification of the colonies into each group. The jackknife procedure gave the same classification results i.e. $100 \%$ overall correct classification rate. A significant difference was found between the means of the three biometric groups $(\Lambda=0.02658$ with $(8,2,56) \mathrm{df}, \mathrm{F}=31.5$ with $(16,98) \mathrm{df}, P<0.0001)$. These results support the findings of Singh et al. (1990). Eight of the 22 morphometric characters which entered the discriminant function in descending order of discriminatory power are (48), (50), (49), (4), (31), (20), (42), and (10).

A factor analysis carried out using the 121 colonies from the Uttar Pradesh and Nepal regions alone (morphocluster III) at a mean sampling distance resolution of approximately $50 \mathrm{~km}$ also revealed morphological differences amongst the localities. Six factors with eigenvalues greater than one were isolated accounting for $77.4 \%$ of variation in the data. The factor scores plot delineated three biometric groups: the colonies from northwestern Uttar Pradesh (localities 21-27, 29, excluding 25) forming group (a); those from northeastern Uttar Pradesh and western Nepal (localities 25, 28, 31-36) forming a second group (b); and those from central and eastern Nepal (localities 39-48) group (c) (Fig. 2). The colonies from Ghughuti 37 and Vinaula 38 were assigned to the right-hand half of the factor plot indicating that larger bees were present at these two higher altitude localities in Nepal.

A discriminant analysis supported the three biometric groups with $100 \%$ correct classification of the 19 colonies into group (a) (northwestern Uttar Pradesh), 100\% correct classification of the 51 colonies into group (b) and $95.8 \%$ correct classification of the 48 colonies ( 2 colonies misclassified) into group (c). The overall classification rate was $98.3 \%$ which reduced to $95.9 \%$ when the jackknife procedure was applied. Ten morphometric characters entered the discriminant function in descending order of discriminatory power (49), (48), (13), (20), (54), (36), (11), (55), (5), and (4). A significant difference was found between the means of the three biometric groups $(\Lambda=0.0257$ with $(10,2,118) \mathrm{df}, \mathrm{F}=57.1$ with $(20,218) \mathrm{df}, P<0.0001)$.

Finally, a factor analysis and discriminant analysis carried out on the colonies from the Kashmir region, Himachal region, Nepal (localities 39-48), and Manipur with a mean sampling distance resolution between regions of approximately $480 \mathrm{~km}$ revealed four distinct morphoclusters. Three factors with eigenvalues greater than one were isolated, which accounted for $86.2 \%$ of the variation in the data, and 12 morphometric characters entered the discriminant function in descending order of discriminatory power (48), (45), (54), (13), (1), (55), (37), (10), (20), (36), (49), and (26). 100\% correct classification of the colonies into all 4 morphoclusters was established and verified by the jackknife procedure.

The intercolonial variances at the 64 localities were determined using the first factor loadings. Significantly higher variations were found at the following localities: 7 and 8 (between morphoclusters I and II); 21 (between morphoclusters II and III); 27 and 29 (between biometric groups 1 and 2 within morphocluster III); 44 (in biometric group 3 within morphocluster IV); and 60 
and 61 (in biometric group 2 within morphocluster IV) (Levene's F = 2.16 with (63, 215) df, $P<0.0001)$.

Significant positive correlations were found between the morphological characters associated with the size of the honeybees and the altitudes of the localities at which they were sampled. For example, the correlation between the forewing length (5) and altitude using all 64 localities was highly significant $(r=0.63, P<0.0001)$. The results confirm the findings of Verma et al. (1994) for groups I and II, Verma et al. (1989) for group III and Singh et al. (1990) for group IV.

\section{DISCUSSION}

Elucidation of the complex structure of A. cerana populations in the southern Himalayan region is facilitated in a graphical, historical context (Fig. 1). Earlier studies demonstrated that honeybees of the western subregion were generally larger and darker with increasing altitude (Kapil, 1956; Narayanan, 1960, 1961a,b; Kshirsagar, 1973). Subsequent univariate analyses suggested two distinct morphoclusters, one in Kashmir the other in Himachal Pradesh (Mattu and Verma, 1983, 1984a,b), a conclusion also reached in later multivariate analyses (Verma et al., 1994). Interestingly, there were no intermediate or clinal forms between these two clusters.

Two additional morphoclusters were described from the central Himalayan region of Nepal, one from the Terai plains, the other from the midland hills (Fig. 1). Again, correlations between some morphological characters and altitude were reported (Verma et al., 1989). Moreover, the two Nepali clusters were shown to be distinctly different from the clusters of Kashmir and Himachal Pradesh to the west and those of the east in Nagaland (Manipuri bees). However the inter-cluster average sampling distance was about $500 \mathrm{~km}$ (Fig. 1). A further analysis of the eastern subHimalayan region yielded three additional morphoclusters designated as Nagaland, Brahmaputra, and Himalaya (Singh et al., 1990; Singh and Verma, 1993; Fig. 1). Verma (1995) also noted that the bees became progressively smaller from west to east. Interestingly, this clinal pattern is also mirrored in a north-south cline for the Indian subcontinent which DinizFilho et al. (1993) observed in a re-analysis of the Kshirsagar (1981) data set. While the above analyses were multivariate in approach, they were nevertheless statistically independent and unrelated studies of the western, central, and eastern Himalayan subregions with large interregional data gaps.

There are four statistically discrete morphoclusters for the whole region (Fig. 2). Three of these morphoclusters (cluster I Kashmir, II Himachal Pradesh and IV Sikkim, Bhutan, Arunachal Pradesh, Assam, Meghalaya and Nagaland) confirm conclusions reached in earlier, unrelated studies (Verma et al., 1989, 1994; Singh et al., 1990; Singh and Verma, 1993). Likewise, the three biometric subgroups of cluster IV representative of Himalaya, Brahmaputra, and Nagaland confirm the interpretations of others (Singh et al., 1990). The major departures from the morphoclusters obtained in previous studies (compare Figs. 1 and 2) essentially arise from the filling of previous lacunae in sampling Uttar Pradesh and the greater part of Nepal. Now that these gaps have been filled, a more contiguous run of data show that Uttar Pradesh and Nepal together actually form morphocluster III which is statistically quite discrete from its neighbours. Moreover, this morphocluster is further subdivisable into three biometric groups consisting of the bees of (a) W. Uttar Pradesh, (b) E. Uttar Pradesh and W. Nepal, and, (c) central and eastern Nepal (Fig. 2).

Thus the composite structure for A. cerana in the Himalayan region reveals four primary, major morphoclusters (= subspecies?), two 
of which can be further resolved into three biometric subgroups (Fig. 2). These results are the products of statistical analysis of morphological variation for the region. In reflecting on the clusters shown in Figure 1, Verma (1995) suggested that the morphological groups might well be biologically meaningful because they are geographically separated. However, in biological terms the four morphoclusters and six biometric subgroups of Figure 2 still require explanations as to their biological meaningfulness as separate populations.

The analysis of the climatic zones for this botanically palaeotropical part of Eurasia shows that the whole region has a warm temperate, rainy climate with dry winters in the system of Köppen and Geiger (cf. Müller, 1982); alternatively, in the system of Troll and Paffen (cf. Müller, 1982), Kashmir alone falls into the subtropical steppe while the rest of the transect from Himachal Pradesh through Nagaland is classically tropical but with varying rainfall. Physiographical changes in the southern Himalayan region are quite pronounced with respect to altitude and, indeed, increases in honeybee size are correlated with increasing altitude. This physiographic differentiation is strongly reflected in defining the boundaries of the four major morphoclusters because the seasonality of reproductive swarming varies with altitude, not longitude, in the southern Himalayan region (Tab. I). Consequently, whichever the morphocluster region, swarming usually begins in mid-February in lowland valleys and on plains below $1000 \mathrm{~m}$. At intermediate altitudes (1000-1500 m) swarming commences in mid-March and at higher and more temperate levels (1500-3000 m) swarming is delayed until early April (Verma, unpublished observations).

The effect of this variation for the onset of swarming is that significant temporal reproductive barriers exist between adjacent morphoclusters of $A$. cerana. For example, in the morphocluster I region $88 \%$ of swarming begins in April while for morphocluster II $50 \%$ of swarming begins in February/March $\left(\chi^{2}=7.74,2 \mathrm{df}, P=0.0208\right)$. A combination of clusters I and II shows that $65 \%$ of swarming begins in April while in region III $61 \%$ occurs in February/March. Swarming in the morphocluster III region is also significantly different from that of IV $\left(\chi^{2}=10.60,4 \mathrm{df}, P=0.0314\right)$. So while there is certainly a degree of temporal overlap in the swarming periods of adjacent morphoclusters of A. cerana, there are also substantial and significant periods of temporal isolation between them as well. This effect has also been noted for morphoclusters of A. mellifera (Hepburn and Radloff, 1998).

In the analysis of honeybee population structure considerable insight about genetic variability and gene flow is reflected in the variance characteristics of a particular trait. In the case of African A. mellifera, variance domains occur at transitions between differing ecological or climatological zones and represent zones of hybridization (Hepburn and Radloff, 1998). In the case of southern Himalayan A. cerana, ten high variance domains occur (Fig. 2) nearly all of which are situated at or near borders between morphoclusters $(21,29)$, their biometric subgroups $(27,51,52,60)$, or areas of rapid physiographic change $(7,8)$. In the absence of complete temporal reproductive isolation, it is inferred that these high variance areas result from introgressive hybridization between adjacent morphoclusters and biometric groups. Such an interpretation could benefit from additional confirmation using DNA probes.

A final matter concerns subspecific classification of these A. cerana honeybees. In a recent review of this problem it was shown that subspecific categories are riddled with anomalies and are biologically tenuous at best (Hepburn et al., 2001). Previously, Engel (1999) analysed and corrected the subspecific nomenclature for $A$. cerana by rigorous application of the rules of the International Code of Zoological Nomenclature. This was a matter of rules for names, not 
comment on biological entities. In any event, in his assessment the two morphoclusters representing Kashmir and Himachal Pradesh would be A. cerana cerana while both morphoclusters III and IV would be the subspecies A. cerana skorikovi. However, all four morphoclusters obtained by multivariate morphometric analysis (Fig. 2, Tab. II) enjoy equal statistical and morphometric status and all four would fully qualify as morphological subspecies of $A$. cerana just as for subspecies of A. mellifera (Ruttner, 1988). We believe that it is too soon to assign ICZN-based names to morphoclusters (= subspecies?) of A cerana in general; and, for the Himalayan region, believe that it is first necessary to characterize their honeybee neighbours in Tibet to the north, Myanmar in the east, India to the south and Pakistan and Afghanistan to the west. Moreover, the philosophical and practical basis for the subspecies concept is fraught with problems and should probably be abandoned (e.g., Wilson and Brown, 1953).

\section{ACKNOWLEDGEMENTS}

We thank M. Engel, P. Neumann and D.R. Smith for constructive discussions on this manuscript.

Résumé - Analyse morphométrique des populations d'Apis cerana du versant sud de l'Himalaya. Des échantillons d'ouvrières d'Apis cerana Fabr. ont été prélevés le long d'un transect de $2200 \mathrm{~km}$ allant du Pakistan au Myanmar sur le versant sud de l'Himalaya. Leurs caractéristiques morphométriques ont été étudiées à l'aide de l'analyse factorielle et de l'analyse discriminante d'une analyse multivariée. Au total 3704 abeilles provenant de 64 colonies ont été étudiées individuellement. La résolution de la distance d'échantillonnage était de $50 \mathrm{~km}$ (Tab. I). Vingt-deux caractères sur les 55 mesurés ont suffit à séparer des « morphoclusters » (groupes caractérisés par un ensemble de caractères morphométriques).
Quatre morphocluters ont été déterminés : I Cachemire, II Himachal Pradesh, III Uttar Pradesh et Népal occidental et IV Népal central et oriental, Sikkim, Arunachal Pradesh, Bengale et Nagaland (Figs. 2 et 3). En outre les morphoclusters II et III ont été subdivisés en trois sous-groupes biométriques : III (a) Uttar Pradesh du nord-ouest, (b) Uttar Pradesh du nord-est et Népal oriental et (c) Népal occidental ; IV (a) avantmonts orientaux de l'Himalaya au Sikkim, Arunachal Pradesh central et Népal oriental, (b) vallée du Brahmapoutre et collines de Khasi, (c) Nagaland, Manipur et Mizoram (Fig. 2).

Ces résultats proviennent d'une combinaison de données précédemment publiées pour 44 localités (Verma et al., 1989, 1994 ; Singh et al., 1990) et de données provenant de 20 localités complémentaires qui ont comblé des lacunes cruciales pour le transect du versant sud de l'Himalaya. D'après leur statut statistique les quatre morphoclusters définis ici correspondent à des sous-espèces séparées (mais non dénommées en tant que telles) et n'entrent dans le cadre d'aucune nomenclature disponible couramment utilisée pour A. cerana.

Les données diffèrent de celles d'études antérieures (Fig. 1), parce que la résolution d'échantillonnage a été accrue et les lacunes de l'Uttar Pradesh et de la plus grande partie du Népal comblées. Les morphoclusters sont statistiquement distincts en ce qui concerne le début de l'essaimage de reproduction et ceci procure un certain degré d'isolement reproductif temporel entre les morphoclusters adjacents.

\section{Apis cerana / génétique populations / morphométrie / Himalaya méridional}

\section{Zusammenfassung - Morphometrische Analyse der Apis cerana - Populationen in der Region des südlichen Himalaya. Auf einem über $2200 \mathrm{~km}$ langen von Pakistan bis Myanmar reichenden Transekt durch das Gebiet des südlichen Himalaya wurden}


Arbeiterinnenproben von Apis cerana Fabr. gesammelt. Ihre morphometrischen Eigenschaften wurden mit der Faktorenanalyse und mit der Diskriminanzanalyse einer multivariaten Analyse untersucht. Insgesamt wurden 3704 Einzeltiere von Völkern aus 64 Sammelorten in einer Sammeldistanzauflösung von $50 \mathrm{~km}$ untersucht (Tab. I). 22 der 55 Messungen waren für eine Trennung der Morphokluster ausreichend.

Die Morphokluster liessen sich, von West nach Ost, auf folgende Gebiete eingrenzen: I auf Kaschmir, II Himachal Pradesh, III Uttar Pradesh und westliches Nepal, und IV zentrales und östliches Nepal, Sikkim, Arunachal Pradesh, Bengalen und Nagaland (Abb. 2 und 3). Darüber hinaus waren Morphokluster III und IV jeweils in drei biometrische Gruppen unterteilbar: III (a) nordwestliches Uttar Pradesh (b) nordöstliches Uttar Pradesh und östliches Nepal und (c) westliches Nepal; IV (a) östliches Fußgebirge des Himalaya in Sikkim, zentralem Arunachal Pradesh und östlichem Nepal; (b) Brahmaputratal und Khasihügel, (c) Nagaland, Manipur und Mizoram (Abb. 2).

Diese Ergebnisse wurden auf Grund einer Kombination von Daten erarbeitet, die bereits zuvor für 44 Orte publiziert worden waren (Verma et al., 1989, 1994; Singh et al., 1990), ergänzt durch Proben von 20 weiteren Orten, durch die bedeutende Lücken des Transekts durch den südlichen Himlaya geschlossen wurden. Nach ihrem statistischen Status entsprechen die hier aufgezeigten Morphokluster getrennten Subspezies (werden allerdings nicht als solche benannt) und passen nicht in irgendeine der derzeitig verfügbaren Nomenklaturen von A. cerana.

Die Ergebnisse unterscheiden sich von früheren Studien (Abb. 1) durch die dichtere Auflösung der Proben und die Auffüllung der Sammlungslücken in Uttar Pradesh und dem größten Teil von Nepal. Die Morphokluster unterscheiden sich im Hinblick auf den Beginn der reproduktiven Schwarmtätigkeit. Dadurch ergibt sich bis zu einem gewissen Grad eine zeitliche reproduktive Isolation zwischen aneinandergrenzenden Morphokluster.

\section{Apis cerana / Honigbienen / Morphoklu- ster / Populationen / südliches Himala- yagebiet}

\section{REFERENCES}

Damus M.S., Otis G.W. (1997) A morphometric analysis of Apis cerana F. and Apis nigrocincta Smith populations from southeast Asia, Apidologie 28, 309-323.

de la Rúa P., Simon U.E., Tilde A.C., Moritz R.F.A., Fuchs S. (2000) mtDNA variations in Apis cerana populations from the Philippines, Heredity 84 , 124-130.

Deowanish S., Nakamura J., Matsuka M., Kimura K. (1996) mtDNA variation among subspecies of Apis cerana using restriction fragment length polymorphism, Apidologie 27, 407-413.

Diniz-Filho J.A.F., Malaspina O., Pignata M.I.B. (1993) Geographic variation in Apis cerana indica F.: a spatial autocorrelation analysis of morphometric patterns, J. Apic. Res. 32, 65-72.

Engel M.S. (1999) The taxonomy of recent and fossil honey bees (Hymenoptera: Apidae; Apis), J. Hym. Res. 9, 165-196.

Hepburn H.R., Radloff S.E. (1998) Honeybees of Africa, Springer-Verlag, Berlin.

Hepburn H.R., Smith D.R., Radloff S.E., Otis G.W (2001) Infraspecific categories of Apis cerana: morphometric, allozymal and mtDNA diversity, Apidologie 32, 3-23.

Johnson R.A., Wichern D.W. (1998) Applied Multivariate Statistical Analysis, 4th ed., Prentice Hall, Upper Saddle River, New Jersey.

Kapil R.P. (1956) Variation in biometrical characters of the Indian honey-bee (Apis indica F.), Indian J. Entomol. 18, 440-457.

Kshirsagar K.K. (1973) Comparative biometric studies on Indian honeybees. III. Preliminary observations on biometry of Apis cerana $\mathrm{F}$. queen, Indian Bee J. 35, 21-26.

Kshirsagar K.K. (1981) Morphometric studies on Apis cerana indica $\mathrm{F}$ worker. III. Effect of geographical position on morphometric characters, Indian Bee J. 43, 1-5.

Lachenbruch P., Mickey R.M. (1968) Estimation of error rates in discriminant analysis, Technometrics $10,1-11$.

Mattu V.K., Verma L.R. (1983) Comparative morphometric studies on introduced European bee Apis mellifera L. and Indian honeybee Apis cerana indica F., Proc. 2nd Int. Conf. Apic. Trop. Climates, Himachal Pradesh, pp. 262-277. 
Mattu V.K., Verma L.R. (1984a) Comparative morphometric studies on the Indian honeybee of the north-west Himalayas. 2. wings, J. Apic. Res. 23 , $3-10$.

Mattu V.K., Verma L.R. (1984b) Comparative morphometric studies on the Indian honeybee of the north-west Himalayas. 3. hind leg, tergites and sternites, J. Apic. Res. 23, 117-122.

Müller M.J. (1982) Selected Climatic Data for a Global Set of Standard Stations for Vegetation Sciences, Junk, The Hague.

Narayanan E.S., Sharma P.L., Phadke K.G. (1960) Studies on biometry of the Indian bees. 1. Tongue length and number of hooks on the hind wings of Apis indica F., Indian Bee J. 22, 58-63.

Narayanan E.S., Sharma P.L., Phadke K.G. (1961a) Studies on biometry of the Indian bees. III. Tongue length and number of hooks on the hind wings of Apis indica F. collected from Madras State, Indian Bee J. 23, 3-9.

Narayanan E.S., Sharma P.L., Phadke K.G. (1961b) Studies on biometry of the Indian bees. IV. Tongue length and number of hooks on the hind wings of Apis indica F. collected from Uttar Pradesh, Indian Bee J. 23, 69-74.

Ruttner F. (1988) Biogeography and Taxonomy of Honeybees, Springer-Verlag, Berlin.

Sasaki M. (1994) Comparative evaluation of southern and northern Apis cerana ecotypes and points which should be considered for future breeding, Honeybee Sci. 15, 99-106 (in Japanese, English summary).

Sihanuntavong D., Sittipraneed S., Klinbunga S. (1999) Mitochondrial DNA diversity and population structure of the honeybee, Apis cerana, in Thailand, J. Apic. Res. 38, 211-219.
Singh M.P., Verma L.R. (1993) Morphometric comparison of three geographic populations of the northeast Himalayan Apis cerana, in: Connor L.J., Sylvester H.A., Wongsiri S. (Eds.), Asian Apiculture, Wicwac, Cheshire, pp. 67-80.

Singh M.P., Verma L.R., Daly H.V. (1990) Morphometric analysis of the Indian honeybee in the northeast Himalayan region, J. Apic. Res. 29, 3-14.

Smith D.R., Villafuerte L., Otis G., Palmer M.R. (2000) Biogeography of Apis cerana F. and Apis nigrocincta Smith: Insights from mtDNA studies, Apidologie 31, 265-280.

Sylvester H.A., Limbipichai K., Wongsiri S., Rinderer T.E., Mardan M. (1998) Morphometric studies of Apis cerana in Thailand and the Malaysian peninsula, J. Apic. Res. 37, 137-145.

Tilde A.C., Fuchs S., Koeniger N., Cervancia C.R. (2000) Morphometric diversity of Apis cerana Fabr. within the Philippines, Apidologie 31, 249-263.

Verma L.R. (1995) Apis cerana: biometric genetic and behavioural aspects, in: Kevan (Ed.), The Asiatic Hive Bee, Enviroquest, Cambridge, pp. 41-53.

Verma L.R., Mattu V.K., Daly H.V. (1994) Multivariate morphometrics of the Indian honeybee in the northwest Himalayan region, Apidologie 25, 203-223.

Verma L.R., Kafle G.P., Sharma A., Mattu V.K. (1989) Biometry of Apis cerana of Nepal Himalayas, in: Proc. 4th Int. Conf. Apic. Trop. Climates, pp. $458-465$.

Wilson E.O., Brown W.L. Jr. (1953) The subspecies concept and its taxonomic application, Syst. Zool. 2 , 97-111. 